This authors' personal copy may not be publicly or systematically copied or distributed, or posted on the Open Web, except with written permission of the copyright holder(s). It may be distributed to interested individuals on request.

\title{
REVIEW
}

\section{Climate change response of vegetation across climatic zones in Italy}

\author{
Stefano Chelli ${ }^{1, *}$, Camilla Wellstein ${ }^{2}$, Giandiego Campetella $^{1}$, Roberto Canullo ${ }^{1}$, \\ Rita Tonin' ${ }^{2}$, Stefan Zerbe ${ }^{2}$, Renato Gerdol ${ }^{3}$ \\ ${ }^{1}$ School of Biosciences and Veterinary Medicine, Plant Diversity and Ecosystems Management Unit, University of Camerino, \\ Via Pontoni 5, 62032 Camerino, Macerata, Italy \\ ${ }^{2}$ Faculty of Science and Technology, Free University of Bozen-Bolzano, Piazza Università 5, 39100 Bozen, Italy \\ ${ }^{3}$ Department of Life Sciences and Biotechnology, University of Ferrara, Corso Ercole I d'Este 32, 44121 Ferrara, Italy
}

\begin{abstract}
Italy represents a good model region for assessing vegetation responses to changing climate across a broad climatic range, from Mediterranean warm-dry climate to alpine coldhumid climate. We reviewed results of studies analysing the response of natural vegetation to climate change in Italy, published until July 2016 in peer-reviewed journals. Evidence provided by these studies shows that climate warming is expected overall to enhance plant growth in Italy, but the magnitude of growth stimulation will probably vary among climatic zones, with stronger effects in the cold regions of the alpine climatic zone. Drought, induced by reduced precipitation and/or increased evapotranspiration, can override the positive effects of higher temperatures on plant growth, not only in the Mediterranean warm-dry climatic zone but also in the less dry subMediterranean climatic zone and even in the temperate one. Our review highlighted 2 major research gaps to which future research should be directed. First, there is poor knowledge of how species composition will change in response to changing climate and how this will affect ecosystem functioning in Mediterranean to temperate ecosystems. Second, there is poor knowledge of possible interactions between climate-induced vegetation changes and dynamic processes related to land-use changes.
\end{abstract}

KEY WORDS: Climate change $\cdot$ Drought $\cdot$ Experimental study $\cdot$ Italy $\cdot$ Observational study · Warming $\cdot$ Review

\section{INTRODUCTION}

Global climate change is, along with anthropogenic land-use changes, one of the major drivers of biodiversity loss in terrestrial ecosystems (Sala et al. 2000, Thomas et al. 2004). While the long-term change in global climate is not yet certain (IPCC 2013), it will likely have profound effects, shifting terrestrial ecosystems outside their historical range of climate variability. There is therefore a need to predict how natural vegetation will respond to climate change in order to propose adaptation measures and draw recommendations for future land use (Thomas et al. 2004, Suttle et al. 2007).

Associated with changing global climate, alterations in (1) functioning of organisms (phenology and physiology; Fitter \& Fitter 2002, Gutschick \& BassiriRad 2003, Nicotra et al. 2010), (2) distribution and abundance of species (Hughes 2000, Root et al. 2003, Thomas et al. 2004), (3) composition of and interactions within communities (Kardol et al. 2010, Michalet et al. 2014) and (4) ecosystem processes (Chapin 2003, 
Hsu et al. 2012) are already occurring and will continue to occur in the future (Walther et al. 2002). This is due to changes in mean temperature and precipitation, as well as in modifications of their seasonal and yearly variability, including extreme weather events (Walther et al. 2002, Thomas et al. 2004, Jentsch et al. 2007, IPCC 2013, Reyer et al. 2013).

Predictions of plant responses to climate change may be derived from trend-based observational studies (mainly by means of spatial gradients, i.e. spacefor-time substitution, and temporal gradients, i.e. the re-visitation approach), experimental manipulations, and modelling approaches (Dunne et al. 2004); these can, however, produce opposing outcomes (Sandel et al. 2010, Metz \& Tielbörger 2016). Observational studies often consider broader spatial and temporal scales, but generally suffer from lack of control over covariates (Sandel et al. 2010). In contrast, experimental studies are typically limited in spatial and temporal transferability (Rustad 2006), but they are particularly effective in simulating differing magnitudes and frequencies of extreme events (Jentsch et al. 2007). Studies based on experimental approaches have initially focused on single plants or simple assemblages in greenhouses and botanical gardens (Fox et al. 1999). More recently, in situ experiments have been carried out in natural and complex communities for addressing scientific questions requiring understanding of integrated ecosystem responses to extreme environmental changes (Yahdjian \& Sala 2002).

Some regions seem to be more sensitive to climate changes than others. For example, the Mediterranean region is characterized by a climate of transition between the temperate mid-latitude and sub-tropical dry climate, and is, consequently, potentially very sensitive to climate change (Cubasch et al. 1996, Lavorel et al. 1998, Thuiller et al. 2005). Moreover, Mediterranean ecosystems will likely experience the greatest proportional change in biodiversity because of the substantial influence of the major drivers of biodiversity alterations (i.e. land-use change, Sala et al. 2000). Similarly, high-elevation ecosystems in mountainous regions appear to be particularly vulnerable mainly due to significant changes in regime and abundance of rainfall, in snow-cover duration as well as in glacier extent (Theurillat \& Guisan 2001, ISAC-CNR 2009).

In this context, Italy represents an interesting model region that spans a broad climatic gradient ranging from Mediterranean, across sub-Mediterranean and temperate up to alpine climate, sheltering a broad variety of 'close-to-natural' ecosystems, managed semi-natural ecosystems and agro-ecosystems.
As part of the Mediterranean biodiversity hotspot (Myers et al. 2000), Italy hosts $>7000$ vascular plant species (Conti et al. 2005), with $18.9 \%$ of the total national vascular flora being endemic (Peruzzi et al. 2014). In several southern regions, mainly islands, endemic taxa represent $>20 \%$ of the local flora. This high diversity level is related to a strong biogeographical gradient, ranging from the Alps to the Mediterranean, as well as to the long history of human exploitation and management practices (FadyWelterlen 2005, Colombaroli \& Tinner 2013).

In this study, we review experimental and observational studies carried out in Italy with the objective of analysing the effects of climate change on terrestrial plant species and vegetation. Our study aimed to (1) present an overview of the Italian 'state of the art' of studies on climate change, (2) discuss and summarize the results across different climatic zones and (3) identify gaps and future research perspectives.

\section{METHODS}

\subsection{Climate change in Italy}

Based on model projections, the Mediterranean region can be considered a climatic change hotspot, particularly sensitive to global warming (Giorgi 2006). An increase in mean temperature and precipitation variability is predicted for Italy and the whole of Europe (Giorgi \& Lionello 2008, Elguindi et al. 2013, Simolo et al. 2014). Recent studies have provided increasing evidence of ongoing climate change in Italy (Brunetti et al. 2002, Tomozeiu et al. 2006, Senatore et al. 2011, Zampieri et al. 2012, Viola et al. 2014, Caloiero et al. 2015, Piccarreta et al. 2015). Some of these papers analysed temperature and precipitation trends that occurred over the past decades.

Analyses of time series of temperature showed a general increase in annual mean values across the whole Italian peninsula during the last century (Brunetti et al. 2004, Simolo et al. 2010), with the Alps expected to experience warming trends twice as large as the global ones (Kotlarski et al. 2012, Gobiet et al. 2014). Some studies (Brunetti et al. 2002, 2004) reported a decrease in precipitation events and an increase in their intensity over more than a century, but with patterns differing between the mountainous areas (i.e. northern Italy and the mountainous regions of central-southern Italy including the alpine, temperate and sub-Mediterranean climatic zone) and the coastal regions and islands of southern Italy (i.e. the Mediterranean climatic zone). In particular, a slight decrease 
in precipitation and a significant change in the timing of precipitation, with a lower number of rainy days, higher intensity of rainfall and increased duration of periods without precipitation, have been reported (ISAC-CNR 2009). In future decades, we will probably face an increase in weather extremes both in the sense of heavy rainfall and summer heat waves, with a high incidence of drought (ISAC-CNR 2009). In contrast, low temperature extremes will be less frequent in winter (Giorgi \& Lionello 2008).

Regional climate projections in the alpine climatic zone indicate that annual mean temperature is expected to become 0.25 and $0.36^{\circ} \mathrm{C}$ warmer per decade during the first and the second half of the 21st century, respectively (Gobiet et al. 2014). This will lead to accelerated ice melting and reduced glacierfeeding snowfall and thus to a consequent rapid retreat of glaciers (Haeberli et al. 2007). Precipitation is predicted to decline in summer and even more so in winter, with winter precipitation being mostly rain instead of snow, leading to a drastic reduction of snow cover, especially in spring (Steger et al. 2013, Gobiet et al. 2014). Consequently, frost events in spring may become more frequent due to earlier snowmelt time (Scheifinger et al. 2003).

Trend projections are similar for the temperate climatic zone (i.e. the montane belt in the Alps and the Apennines). In the sub-Mediterranean climatic zone (i.e. Po valley, hilly regions of central-southern Italy), increasing temperature during the whole century and decreasing precipitation in summer and increasing precipitation in winter are expected (Tomozeiu et al. 2006, Turco et al. 2013). Conversely, in the Mediterranean climatic zone (i.e. coasts, islands, inland areas of southern Italy), temperature is expected to increase (Senatore et al. 2011), while precipitation presents a reverse trend, with decreasing precipitation in winter and increasing precipitation in summer (Giorgi \& Lionello 2008, Caloiero et al. 2011, 2015). In coastal areas, the intensity and frequency of extreme weather events, such as floods and storms, will increase, and sea level will rise, with consequent intensification of ongoing erosion processes (Medri et al. 2013).

\subsection{Data sources}

We carried out a literature survey until July 2016 in the ISI Web of Science and Google Scholar databases, using appropriate key words (Table S1 in the Supplement at www.int-res.com/articles/suppl/c071 p249_supp.pdf). Only experimental and observational studies performed in Italy were considered, but experimental manipulations realized abroad on plants collected at Italian sites were also included, since they can provide insights on the effects of weather manipulation on plants of different origins. Studies based on modelling approaches, remote sensing, palaeoclimatology, palaeoecology and postfire ecology were excluded, as well as experimental studies exclusively focused on nutrient addition. Studies on the effects of climate change on pollinators, pathogens and herbivores were also excluded.

A total of 90 papers published in peer-reviewed journals were found, with the highest number of papers produced during the last decade (Fig. 1a). For an overview of the main climatic factors and response variables, see Fig. 1b,c. These papers were derived from 61 research projects (each one including papers with the same study sites, treatment or gradient, and sampling design), comprising 26 experimental (Table S2 in the Supplement) and 35 observational ones (Table S3 in the Supplement). There were 238 study sites in these experimental and observational activities, distributed in the 4 climatic zones of Italy (Fig. 2). Among the experiments, 17 were performed ex situ (laboratory or mesocosm), and 8 in the field. One experiment combined field and laboratory activities (Bernareggi et al. 2016). In contrast, observational studies were mainly based on re-visitation of study sites (12 projects) and on the study of contrasting habitats (7) and plant growth markers (7). Seven observational projects used space-for-time substitution, while 2 studied the heat wave of 2003.

The largest number of projects was addressed at the species level (39, of which 20 experimental and 19 observational), 13 projects were carried out at the community level (only observational), 2 projects at the ecosystem level ( 1 observational and 1 experimental), and 7 projects at the cross-level (5 experimental and 2 observational). Details on the partition of the projects at the different levels (species, community, ecosystem, cross-level) are given in Fig. 3.

In the following sections, we discuss the main findings of these papers on vegetation responses to climate change in Italy. We did critically analyse specific methods used in individual papers.

\section{RESULTS AND DISCUSSION}

\subsection{Alpine climatic zone}

Eight experimental projects (resulting in 11 papers) and 17 observational projects ( 25 papers) were found for the alpine climatic zone. Three experiments dealt 

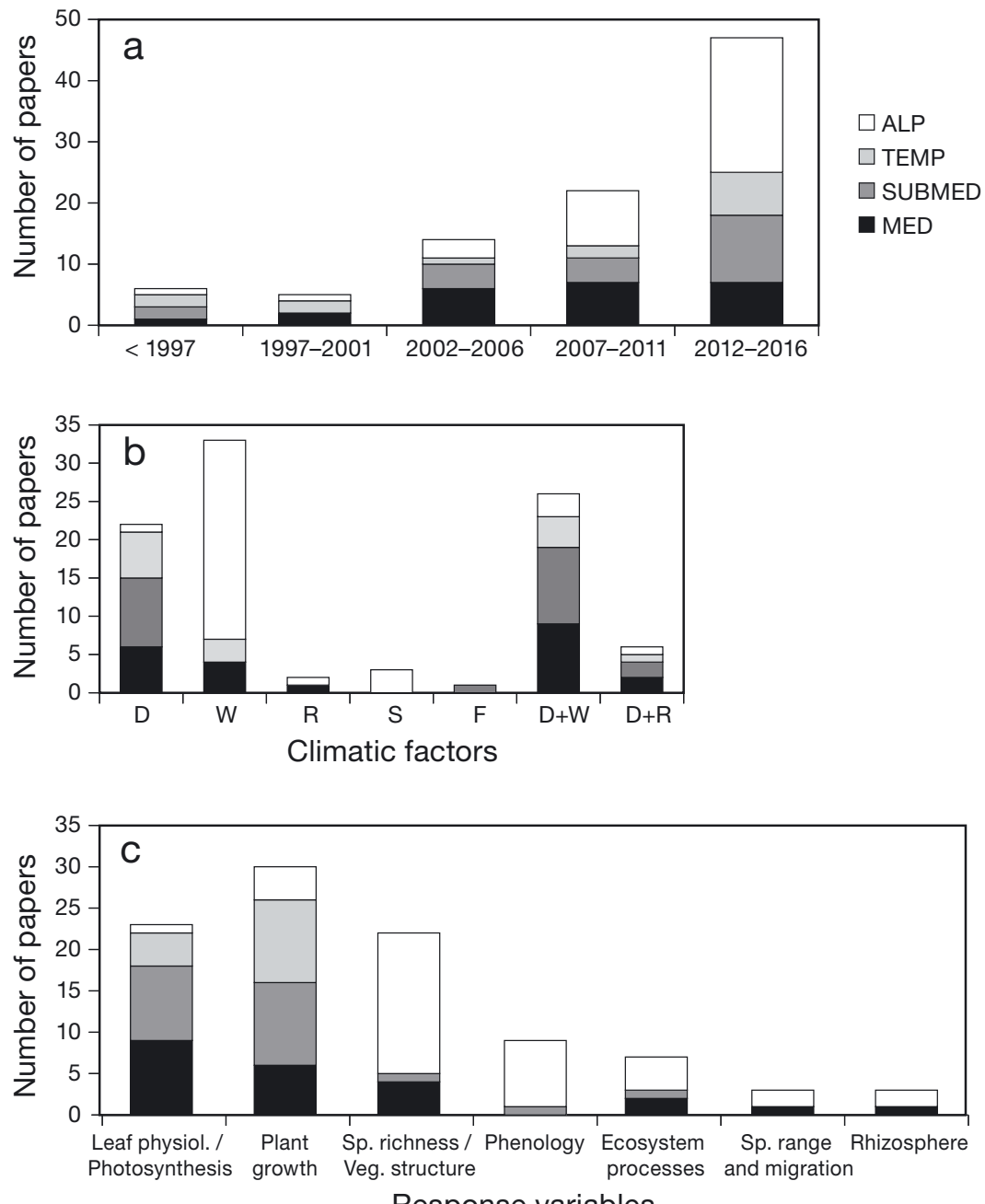

Response variables

Fig. 1. Italian studies on effects of climate change on vegetation in 4 climatic zones (alpine, temperate, sub-Mediterranean, Mediterranean): (a) temporal development of the number of papers; (b) main climatic factors (D: drought; W: warming; R: additional rain; S: snow removal; F: frost); (c) main response variables

with cross-level (ecosystem and community level) responses to simulated climate scenarios (Brancaleoni et al. 2007, Gerdol et al. 2013, Carbognani et al. 2014a). Four experiments addressed the effect of warming on flowering and seed phenology under controlled environmental conditions (Mondoni et al. 2012, 2015, Petraglia et al. 2014, Bernareggi et al. 2015, 2016, Orsenigo et al. 2015, Carbognani et al. 2016). The observational projects mainly focused on community- and species-level responses to climate warming (Abeli et al. 2012a,b, Evangelista et al. 2016, Stanisci et al. 2016). Three observational projects dealt with vegetation dynamics following glacial retreat (Caccianiga et al. 2006, Cannone et al. 2008, Ciccazzo et al. 2014). In line with expectations for future climate scenarios, warming (simulated or recorded along natural gradients), sometimes associated with advanced snowmelt, was revealed as the main driver of environmental changes in the alpine climatic zone (Fig. 1b), while only a few studies dealt with drought. Three main effects of increased temperature emerged from the literature analysis: changes in (1) flowering and seed phenology, (2) species distribution and community structure/composition, and (3) key ecosystem processes.

\subsubsection{Changes in flowering and seed} phenology

Experiments focused on flowering time of snowbed communities revealed a noticeable plastic response to changing micro-climatic conditions, both for snowbed-specialized and alpine generalist species (Petraglia et al. 2014, Carbognani et al. 2016). Petraglia et al. (2014) showed that for many species, flowering time was tuned with temperature. However, Carbognani et al. (2016) highlighted the importance of timescale of the observations: at the annual scale, the timing of snowmelt seemed to play a major role, while at the growing-season timescale, temperature was the most common trigger of the blooming period.

Seed phenology experiments have been performed exposing parental plants or dispersed seeds to warming. Seeds produced by parental plants exposed to $+1.5^{\circ} \mathrm{C}$ showed more resistance to heat, i.e. more viability and less deterioration (Bernareggi et al. 2015), and experienced limited germination/dormancy changes with respect to controls, but the extent of these changes across species could be driven by seed dormancy traits, with deeper dormant species showing major changes in response to incubation temperatures and less dormant species in response to cold stratification periods (Bernareggi et al. 2016). Furthermore, seeds directly exposed to warming after dispersal showed a general increase in germination rate (Mondoni et al. 2015). In detail, the expected increase in spring germination was combined with a relevant increase in 

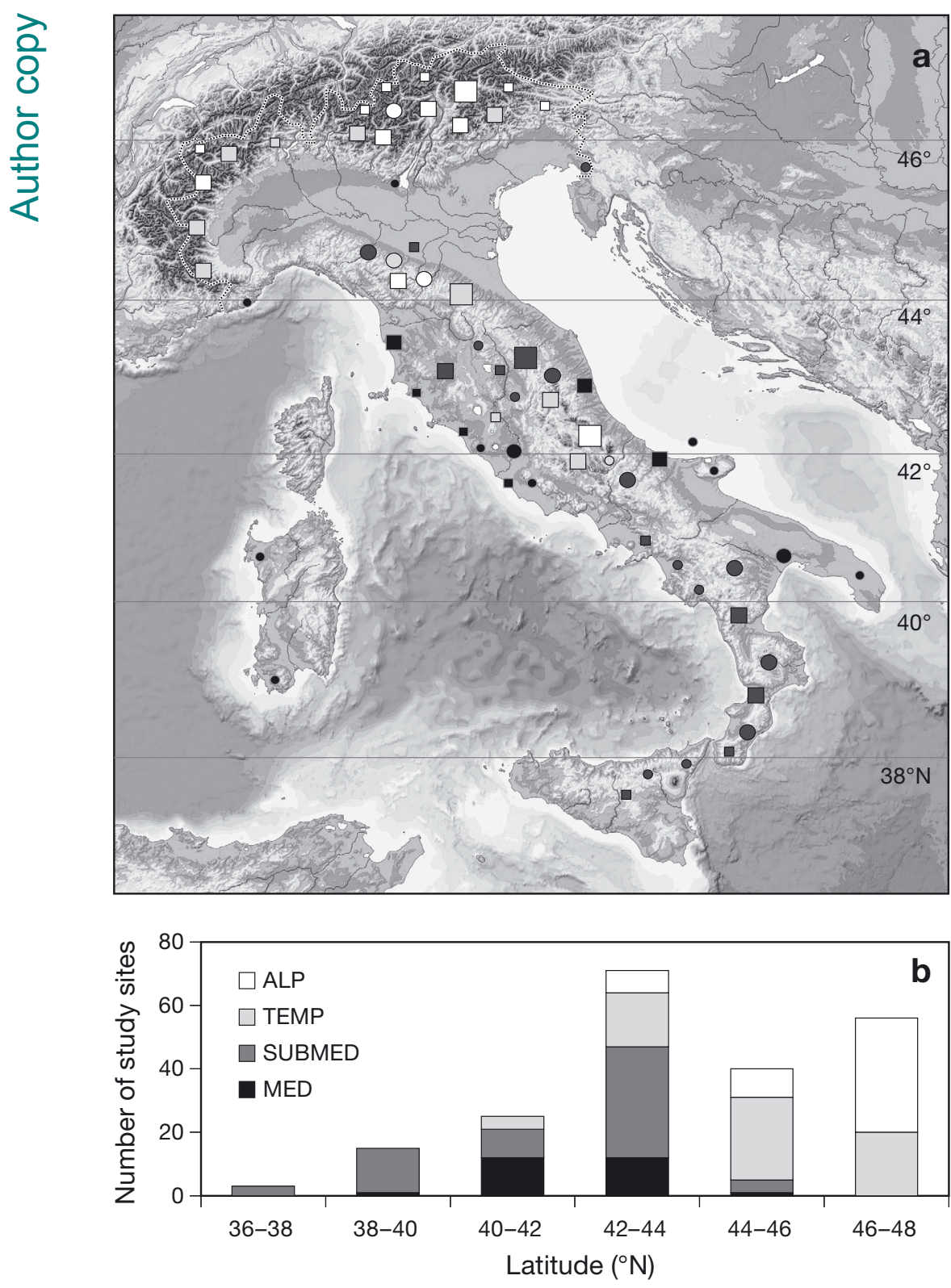

Fig. 2. (a) Location of sampling sites for experimental (circles) and observational (squares) research projects on climate change effects on vegetation. Size of symbols indicates number of sites in the same area (small: 1 site; medium: $2-5$ sites; big: $>5$ sites); colour of symbols indicates climatic zone (black: Mediterranean; dark grey: sub-Mediterranean; light grey: temperate; white: alpine).

(b) Distribution of sampling sites according to latitude and climatic zone

autumn germination. Surprisingly, $60-70 \%$ of seedlings could survive across the winter, revealing an interesting adaptation (Mondoni et al. 2015). Such results have been obtained exposing seeds to moderate and constant warming $\left(+2.7^{\circ} \mathrm{C}\right.$; Mondoni et al. 2015), at the projected $100 \mathrm{yr}$ scenario $\left(+4^{\circ} \mathrm{C}\right.$, Mondoni et al. 2012), and to seasonal heat waves $\left(+6^{\circ} \mathrm{C}_{\text {; }}\right.$ Orsenigo et al. 2015).

\subsubsection{Changes in species pattern and community structure/composition}

Observational projects revealed an increase in species richness and vegetation cover over time in the alpine and subalpine belt in the Alps and the Apennines as a consequence of warming, with increased contribution of thermophilous species and upward migration of shrubs and trees (Pauli et al. 1996, Stanisci et al. 2005, 2016, Cannone et al. 2007, Parolo \& Rossi 2008, Erschbamer et al. 2009, 2011, Evangelista et al. 2016). Such results emerged after a moderate annual warming of $<1.5^{\circ} \mathrm{C}$ in the Alps (Cannone et al. 2007, Parolo \& Rossi 2008) and $1.7^{\circ} \mathrm{C}$ in the Apennines (Evangelista et al. 2016). However, Cannone \& Pignatti (2014), when re-surveying an alpine area after $50 \mathrm{yr}$, surprisingly observed that more than half of the most widespread persisting species exhibited downward shifts instead of upward shifts. Here, climate change probably interacted with land-use change, which can exacerbate the effects of climate warming on the vegetation of mountainous regions (Theurillat \& Guisan 2001). The capability of plant species to migrate can be enhanced by plant functional traits such as small seed mass (Parolo \& Rossi 2008), and can be in turn affected by local morphology and geography (Pauli et al. 1996). Even permafrost decline can play a role (Cannone et al. 2007, Parolo \& Rossi 2008).

The impressive retreat of some $\mathrm{Al}$ pine glaciers (Cannone et al. 2008) seemed to promote quick colonization by ruderal and fast-growing species at the expense of stress-tolerators and typical snowbed species (Caccianiga et al. 2006, Cannone et al. 2008). A case study (Ciccazzo et al. 2014), followed by a review (Ciccazzo et al. 2016), suggested that species-specific selection of microbial communities in the rhizosphere can enhance plant growth in nutrient-poor soils.

Structure and species composition of alpine vegetation was altered by the 2003 heat wave $\left(+2^{\circ} \mathrm{C}\right.$, and $-30 \mathrm{~mm}$ of precipitation during the growing season, with respect to the average; Bragazza 2008), which 

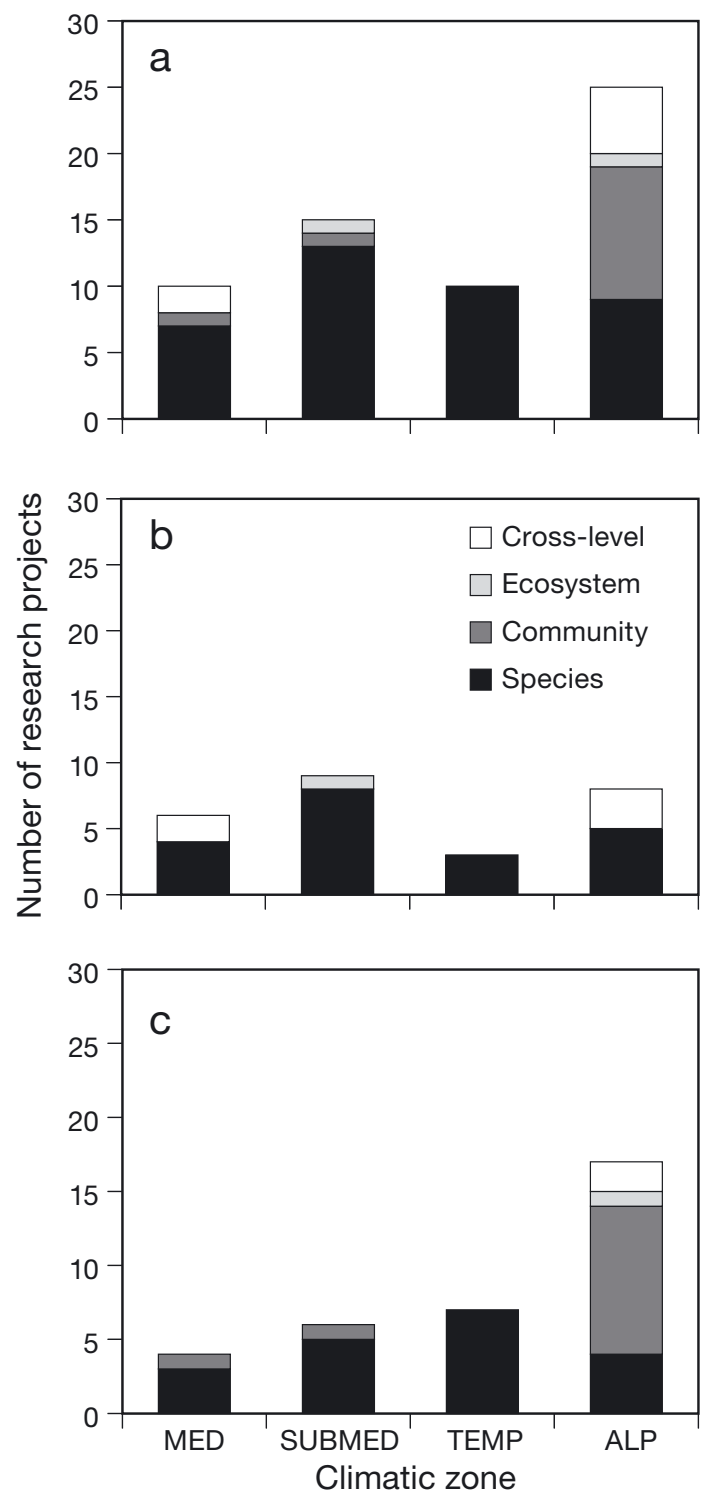

Fig. 3. Distribution of research projects according to different levels of bio-ecological complexity studied and climatic zone for (a) all, (b) experimental and (c) observational projects

triggered a rapid expansion of vascular plant species at the expense of mosses in peatlands (Gerdol et al. 2007, 2008a, Brancaleoni \& Gerdol 2014). The same results have been found in snowbed communities through space-for-time substitution and re-survey approaches (Carbognani et al. 2012, 2014b).

\subsubsection{Changes in key ecosystem processes}

Three important ecosystem processes have been studied in the alpine climatic zone: litter decomposi- tion, above-ground net primary productivity (ANPP) and net photosynthesis. Climate warming has been found to accelerate litter decomposition rates in alpine ecosystems (Carbognani et al. 2014a) due to climate-induced changes in the relative abundance of plant functional types, rather than to direct effects of higher temperature on the activity of decomposing microbes (Bragazza et al. 2013).

ANPP in alpine ecosystems was generally enhanced by warming thanks to longer snow-free periods (Carbognani et al. 2012), but was only marginally affected by experimental irrigation, except in the driest habitats (Brancaleoni et al. 2007). However, a heat wave negatively affected the carbon budget of an alpine peatland, because the unprecedented high temperatures in summer 2003 strongly increased potential evapotranspiration, which lowered the water table even under normal precipitation. The consequent desiccation of the surface peat layers strongly stimulated heterotrophic respiration. This eventually implied negative net photosynthesis rates, i.e. carbon loss, throughout the growing season (Gerdol et al. 2008a).

\subsection{Temperate climatic zone}

Four experimental projects (resulting in 4 papers) and 8 observational projects (10 papers) were found for the temperate climatic zone. All of the experimental and observational projects aimed at assessing the performance of tree species (mainly Fagus sylvatica, Pinus nigra, Larix decidua, Picea abies, Pinus cembra, Pinus sylvestris and Abies alba) under drier and warmer conditions. Only 1 experiment (Beierkuhnlein et al. 2011) examined responses of grass species (Arrhenatherum elatius, Festuca pratensis and Holcus lanatus) to precipitation and temperature manipulation. Two main effects emerged from the literature analysis: changes in (1) growth performance and (2) net photosynthesis and leaf transpiration.

\subsubsection{Changes in growth performance}

The principal parameter used to estimate growth performance of tree species was basal area increment (BAI). Most papers found a positive effect of warming (Motta \& Nola 2001, Gazol et al. 2015) and a negative effect of drought (Piovesan et al. 2008, Levesque et al. 2013, 2014, Gazol et al. 2015) on tree growth (Table 1). However, an interesting pattern emerged when combining the effects of 
increased temperature and decreased water availability. Trees growing under mesic conditions, namely $P$. cembra, L. decidua and $A$. alba, in northern Italy increased their growth performance (Motta \& Nola 2001, Gazol et al. 2015). Here, a role could also be played by changes in nutrient fluxes due to air pollution and/or the fertilization effect of increasing $\mathrm{CO}_{2}$ (Motta \& Nola 2001). In contrast, trees growing under xeric conditions experienced a marked decrease in growth rates, demonstrating that drought stress could override the potential positive effect of higher temperatures (Levesque et al. 2013, 2014). For instance, Piovesan et al. (2008) found that drought stress of the last decades induced a decrease in the growth rates of F. sylvatica, especially at low-altitude sites, with a consequent reduction in productivity of beech forests in the central Apennines. Gazol et al. (2015) demonstrated that $A$. alba populations at xeric sites in central and southern Italy displayed a marked decline in growth associated with increasing aridity. Levesque et al. $(2013,2014)$ found that conifers $(L$. decidua and $P$. abies) occurring at their dry distribution limit were vulnerable to soil water deficit, and if summer becomes drier, tree growth may collapse, inducing dieback. In this case, tree species diversity can act as a buffer that can reduce the risk of losses in ecosystem functionality, as pointed out by a study outside Italy (Mette et al. 2013) for the productivity in central European temperate mixed forests. Rita et al. (2014) pointed out that changes in rainfall patterns could have a significant impact on tree growth (as confirmed also by Piovesan et al. 2008) and species composition in Italian forests, favouring more drought-tolerant species (e.g. a shifting from F. sylvatica to Quercus spp.).

\subsubsection{Changes in net photosynthesis and leaf transpiration}

Experimental studies highlighted the effect of drought on photosynthetic performance, mainly in $F$. sylvatica seedlings (Tognetti et al. 1994, 1995; our Table 2). In particular, water stress caused a significant decline in net photosynthesis, with faster reaction in seedlings from mesic sites. In contrast, seedling populations from xeric sites showed delayed effects of imposed drought (Tognetti et al. 1995). An observational study on adult trees of L. decidua, $P$. cembra and $P$. abies revealed a differential response of leaf transpiration rates to high temperature (Anfodillo et al. 1998). L. decidua maintained relatively
Table 1. Response (-, negative; + , positive; na, not available; nr, no response) of plant species' growth performance to drought and warming in the 4 climatic zones (A: alpine;

$\mathrm{T}$ : temperate; S: sub-Mediterranean; M: Mediterranean)

\begin{tabular}{|c|c|c|c|}
\hline Climate & Species & Drought & Warming \\
\hline A & Pinus mugo & - & + \\
\hline A & Dwarf-shrub heath & na & na \\
\hline $\mathrm{A}$ & Alopecurus alpinus & na & $\mathrm{nr}$ \\
\hline A & Vicia cusnae & na & $\mathrm{nr}$ \\
\hline $\mathrm{A}$ & Sphagnum capillifolium & na & + \\
\hline $\mathrm{T}$ & Pinus cembra & na & + \\
\hline $\mathrm{T}$ & Larix decidua & - & + \\
\hline $\mathrm{T}$ & Picea abies & - & na \\
\hline $\mathrm{T}$ & Abies alba & - & + \\
\hline $\mathrm{T}$ & Fagus sylvatica & - & na \\
\hline $\mathrm{T}$ & Pinus sylvestris & - & na \\
\hline $\mathrm{T}$ & Festuca pratensis & - & + \\
\hline $\mathrm{S}$ & Holcus lanatus & - & $\mathrm{nr}$ \\
\hline $\mathrm{S}$ & Arrhenatherum elatius & - & $\mathrm{nr}$ \\
\hline $\mathrm{S}$ & Sesleria nitida & - & na \\
\hline $\mathrm{S}$ & Abies alba & - & na \\
\hline S & Pinus laricio & - & na \\
\hline S & Quercus pubescens & - & + \\
\hline $\mathrm{S}$ & Pinus nigra & $\mathrm{nr}$ & $\mathrm{nr}$ \\
\hline M & Pinus halepensis & - & na \\
\hline M & Mixed woodland & - & na \\
\hline M & Pinus pinea & - & - \\
\hline M & Cistus monspeliensis & - & $\mathrm{nr}$ \\
\hline M & Helichrysum italicum & $\mathrm{nr}$ & $\mathrm{nr}$ \\
\hline
\end{tabular}

Table 2. Response (-, negative; nr, no response) of species' photosynthetic performance to drought in 3 climatic zones

(T: temperate; S: sub-Mediterranean; M: Mediterranean)

\begin{tabular}{|llc|}
\hline Climate & Species & Drought \\
\hline $\mathrm{T}$ & Fagus sylvatica & - \\
$\mathrm{T}$ & Larix decidua & $\mathrm{nr}$ \\
$\mathrm{T}$ & Pinus cembra & - \\
$\mathrm{T}$ & Picea abies & - \\
$\mathrm{S}$ & Fagus sylvatica & - \\
$\mathrm{S}$ & Alnus cordata & - \\
$\mathrm{S}$ & Pinus laricio & - \\
$\mathrm{S}$ & Pinus halepensis & - \\
$\mathrm{S}$ & Quercus petraea & $\mathrm{nr}$ \\
$\mathrm{S}$ & Quercus cerris & - \\
$\mathrm{S}$ & Sesleria nitida & - \\
$\mathrm{S}$ & Lotus corniculatus & - \\
$\mathrm{S}$ & Thymus longicaulis & - \\
$\mathrm{S}$ & Astragalus sempervirens & - \\
$\mathrm{M}$ & Pinus halepensis & - \\
$\mathrm{M}$ & Mixed woodland & - \\
$\mathrm{M}$ & Cistus monspeliensis & - \\
$\mathrm{M}$ & Quercus ilex & $\mathrm{nr}$ \\
\hline
\end{tabular}


high transpiration rates even during moderate waterdeficit periods (10 d with $<0.4 \mathrm{~mm} \mathrm{~d}^{-1}$ ) due to its water uptake capacity and deep root system, while $P$. abies and $P$. cembra showed a water-saving behaviour. The authors suggested that climate warming may result in a competitive advantage of $L$. decidua over the other 2 species in temperate forests of the Alps.

\subsection{Sub-Mediterranean climatic zone}

Ten experimental projects (resulting in 15 papers) and 7 observational projects (8 papers) were found for the sub-Mediterreanean climatic zone. All of these studies aimed at evaluating (1) growth and (2) photosynthetic performance of tree species (mostly oaks and conifers) under drought and warming. Only 2 observational studies focused on grasslands, one evaluating the intraspecific trait variation in 4 species (Wellstein et al. 2013), and one studying the traitbased response of plant communities along a temperature and precipitation gradient (Tardella et al. 2016). Only 1 experiment (Chelli et al. 2016) analysed the ANPP response to rainfall manipulation in 2 sub-Mediterranean grasslands.

Some experimental studies demonstrated that seedlings and juvenile trees of different origin had several different responses (in terms of growth and photosynthetic performance) to drought, warming and frost treatments. However, only in some cases did plants from drier and warmer provenances seem to be more tolerant to drought and warming treatments (Borghetti et al. 1989, Hu et al. 2013). In contrast, other studies suggested that the response patterns do not reflect local adaptation to local climatic conditions (see Arend et al. 2011, Wellstein \& Cianfaglione 2014). Moreover, plants from colder provenances showed a higher resistance to winter frost treatments (Višnjić \& Dohrenbusch 2004). Leaf palatability was not influenced by drought and warming but differed with respect to origin of the host plants (Backhaus et al. 2014).

\subsubsection{Changes in growth performance}

Similar to the temperate climatic zone, warming improved plant growth performance in the subMediterranean climatic zone as well (Table 1). Arend et al. (2011) and Hu et al. (2013) showed that growth of Quercus pubescens juveniles was significantly stimulated by moderate warming $\left(<2^{\circ} \mathrm{C}\right)$. For the same species, Wellstein \& Cianfaglione (2014) observed an increase of the apical bud-bank in a more intense warming treatment $\left(+2.7^{\circ} \mathrm{C}\right)$. In contrast, drought induced a significant decrease in growth performance (shoot and stem growth, BAI) of $Q$. pubescens and A. alba (Battipaglia et al. 2009, Arend et al. 2011, Hu et al. 2013; our Table 1). An observational study dealing with functional traits of grassland species in mesic versus xeric habitats showed strong phenotypic adaptations in traits related to above- and below-ground growth for the dominant grass Sesleria nitida, with distinct strategies related to soil water content, soil nutrient availability and soil temperature (Wellstein et al. 2013).

A key role in affecting plant growth could be played by changes in early season precipitation, as demonstrated both at the species- (Battipaglia et al. 2009) and the ecosystem-level (Chelli et al. 2016). However, some papers did not find any growth response either to drought ( $-13 \%$ precipitation) or warming $\left(+1.6^{\circ} \mathrm{C}\right)$ in $P$. nigra juveniles (Kreyling et al. 2012, Thiel et al. 2012).

\subsubsection{Changes in net photosynthesis}

Several papers demonstrated a generalized reduction in photosynthetic activity of tree seedlings exposed to drought treatment. In particular, the species negatively affected by drought were $F$. sylvatica, Alnus cordata, Pinus halepensis and Quercus spp. (Table 2). They showed a reduction in net photosynthesis (Borghetti et al. 1989, Tognetti et al. 1995, Michelozzi et al. 2011), leaf relative water content (Tognetti et al. 1995) and stomatal conductance (Borghetti et al. 1989, Michelozzi et al. 2011) as an effect of experimental moderate drought of $<30 \mathrm{~d}$. The reduction in photosynthetic performance was confirmed by an observational study of 4 grassland species (Wellstein et al. 2013), where all grass species showed significantly lower specific leaf area (SLA) under xeric conditions.

The observational study of Grossiord et al. (2014) pointed out the importance of competition for water resources among plant species in determining the response to drought. This study examined pure and mixed forest stands of Quercus cerris and Q. petraea, showing different responses of the 2 species in terms of leaf transpiration and water-use efficiency, with $Q$. petraea exerting a negative effect on $Q$. cerris in mixed forests. Interspecific competition was also important in grassland ecosystems (Wellstein et al. 2014). 


\subsection{Mediterranean climatic zone}

Seven experimental (resulting in 17 papers) and 5 observational (5 papers) projects were found for the Mediterranean climatic zone. Two experiments dealt with ecosystem response to simulated drier and warmer conditions in Mediterranean shrublands (De Dato et al. 2006, Cotrufo et al. 2011), while the others addressed the effects of experimental or ambient conditions on the physiology of Mediterreanean conifers, as well as Quercus ilex and Tamarix africana. Only 2 papers examined the effects of climate change on species composition of coastal dunes (Guidotti et al. 2010, Del Vecchio et al. 2015). In line with the expectations for future climate scenarios, drought (simulated or studied along natural gradients) was revealed as the most important climatic factor in the Mediterranean climatic zone, but few studies dealt with additional precipitation (Fig. 1b). Two main effects emerge from the literature analysis: (1) reduced growth performance and (2) reduced leaf transpiration.

\subsubsection{Changes in growth performance}

Drought caused a reduction in plant growth (i.e. a reducion in shoot and needle elongation, as well as radial growth) both in shrubs (De Dato et al. 2006, Peñuelas et al. 2007, Ripullone et al. 2009) and trees (Borghetti et al. 1998, 2005; our Table 1). An experimental study focused on ecosystem responses to drought revealed lower ANPP and decreased cover of the dominant shrub Cistus monspeliensis after $3 \mathrm{yr}$ of progressive precipitation decline of 6,18 and $46 \%$ in a Mediterranean shrubland (De Dato et al. 2006, Peñuelas et al. 2007). Cover reduction was not observed for other species such as Helichrysum italicum, suggesting a possible change in species composition under drier conditions (De Dato et al. 2006). Another experimental study addressing ecosystem response to drought in Mediterranean woodlands did not find any ANPP reduction, but the amount of precipitation reduction was limited to $10 \%$ (Cotrufo et al. 2011). In contrast, a slight water addition during the summer season enhanced ANPP (Cotrufo et al. 2011). So far, the literature findings indicate that in the Mediterranean climatic zone, ANPP stimulation in wet years is greater than ANPP reduction in dry years.

Studies carried out on Mediterranean shrubs also revealed decreased plant-growth performance in response to reduced water availability, further high- lighting that summer drought plays a central role in limiting plant productivity in Mediterranean ecosystems (Llorens et al. 2003, Ogaya \& Peñuelas 2003). No significant effects of warming were reported, which supports the results of studies suggesting that Mediterranean vegetation is rather insensitive to warming (Peñuelas et al. 2004, 2007).

\subsubsection{Changes in leaf transpiration}

Reduced leaf transpiration through down-regulation of stomatal conductance in Mediterranean plant species resulted in higher water-use efficiency and lower photosynthetic rate. Evidence in this sense was provided for mature shrubs and trees (Borghetti et al. 1998, 2005, Ripullone et al. 2009, De Dato et al. 2013) as well as tree seedlings of Mediterranean conifers and oaks (Tognetti et al. 1997, Gratani et al. 2003, Pesoli et al. 2003, Klein et al. 2013; our Table 2). Interestingly, reduction in leaf transpiration in P. halepensis seedlings was less pronounced at xeric sites compared with mesic sites (Tognetti et al. 1997). This suggests that mechanisms of resistance/tolerance to recurrent drought are more important at xeric sites, while strong adaptation capacity is crucial at mesic sites. Leaf sclerophylly and leaf thickness in $Q$. ilex were higher at xeric sites, and both influenced the capacity to regulate leaf water content (Bussotti et al. 2002, Gratani et al. 2003).

Under Mediterranean climatic conditions, a prompt response of plants to drought is crucial in order to prevent severe tissue dehydration and foliage dieback (Pereira \& Chaves 1993). Regulation of stomatal conductance seems to be one of the most important strategies used by Mediterranean plants to cope with summer drought. In Italy, this mechanism has been demonstrated for shrubs such as Arbutus unedo (Ripullone et al. 2009) and C. monspeliensis (De Dato et al. 2006) and trees such as $P$. halepensis (Tognetti et al. 1997, Borghetti et al. 1998, Klein et al. 2013) and Q. ilex (Bussotti et al. 2002, Gratani et al. 2003). It is likely that down-regulation of stomatal conductance is one of the driving mechanisms responsible for growth reduction of Mediterranean plant species (Ripullone et al. 2009).

\section{CONCLUSIONS AND FUTURE RESEARCH PERSPECTIVES}

Our review has shed light on the responses of terrestrial plants to climate change in Italy, at both the 
species level and the ecosystem level. Even moderate warming $\left(+1.5\right.$ or $\left.+2.0^{\circ} \mathrm{C}\right)$ is expected to influence plant physiological processes either directly or indirectly. Direct effects of warming imply enhanced growth rates, anticipated flowering time and presumably enhanced viability of seeds. Indirect effects of warming are mostly related to snow-cover duration (Kreyling 2010), soil water content (Liu et al. 2016) and soil nutrient availability (Xu et al. 2016) across a broad range of climatic conditions. On the other hand, warming is expected to interact with drought in affecting plant responses to climatic change (Emmett et al. 2004). Indeed, drought can override the positive effects of higher temperatures on plant physiological processes, especially net photosynthesis and growth (see Levesque et al. 2013, 2014). An important finding of this review is that drought may limit plant growth across a broad climatic range, from the Mediterranean zone to the temperate zone. Such projection is far beyond the well-documented evidence of drought-induced growth limitation in summer-dry Mediterranean ecosystems (Peñuelas et al. 2004). Melillo et al. (1993) also found that in regions experiencing only weak drought, plant growth can be already limited by water availability. Increased atmospheric $\mathrm{CO}_{2}$ concentration could increase wateruse efficiency of vegetation in those areas (Melillo et al. 1993), with positive effects on photosynthesis and plant growth. Another important finding of our review is that species-level responses to the combined effects of warming and drought can vary considerably in relation to ecotype across species. Our review also showed that ecosystem-level responses to climate change are likely to override species-level responses to climate change. Important processes such as e.g. upward shift of the treeline, thermophilization of mountain plant communities and shrub encroachment in Mediterranean ecosystems result in alterations in the competitive equilibria among plant species and plant functional types. This can eventually bring about profound changes in the functioning of entire ecosystems.

Our review has highlighted major gaps in our knowledge of the response of vegetation to changing climate in Italy, which suggests some future research topics. There is a general scarcity of community-level or ecosystem-level studies in the warm-temperate climatic zones, where most of the extant data arose from species-level research (Fig. 3), generally focusing on dominant trees. Hence, there is poor knowledge of how species composition will change in response to changing climate in Mediterranean to temperate ecosystems. There is even less knowledge of possible changes in ecosystem functioning, as many ecological processes are strongly affected by species composition. Furthermore, the majority of the studies in these climatic zones were largely focused on woodland and scrubland ecosystems, while too little attention has been devoted to the (semi-)natural ecosystems of meadows and pastures. These ecosystems are likely to undergo dynamic processes deriving from land-use changes which can in turn interact with climate warming to a greater extent compared with close-to-nature habitats. Comparatively more attention has been paid to analyse community responses, as well as to explore consequent effects on ecosystem functioning, in the alpine climatic zone of Italy. However, many of these studies were conducted in northern Italy, i.e. in the Alps and the northern Apennines. Here, climate has no trace of drought during the growing season (Gerdol et al. 2008b). Conversely, few data are so far available for high-altitude habitats on mountains at lower latitudes in Italy, i.e. the central and southern Apennines. These areas experience regular summer drought, as a general climatic feature in all mountainous regions in southern Europe. It is therefore possible that the vegetation of the alpine belt in southern mountain ranges will be increasingly affected by water limitation under a changing climate (Pauli et al. 2012).

Finally, we recommend future research using manipulation/gradient effects on the relevant climatic factors (i.e. temperature, precipitation) in order to facilitate comparisons among studies and climatic zones.

\section{LITERATURE CITED}

Abeli T, Rossi G, Gentili R, Mondoni A, Cristofanelli P (2012a) Response of alpine plant flower production to temperature and snow cover fluctuation at the species range boundary. Plant Ecol 213:1-13

Abeli T, Rossi G, Gentili R, Gandini M, Mondoni A, Cristofanelli $P$ (2012b) Effect of the extreme summer heat waves on isolated populations of two orophitic plants in the north Apennines (Italy). Nord J Bot 30:109-115

Anfodillo T, Rento S, Carraro V, Furlanetto L, Urbinati C, Carrer M (1998) Tree water relations and climatic variations at the alpine timberline: seasonal changes of sap flux and xylem water potential in Larix decidua Miller, Picea abies (L.) Karst. and Pinus cembra L. Ann Sci For 55:159-172

Arend M, Kuster T, Gunthardt-Goerg MS, Dobbertin M (2011) Provenance-specific growth responses to drought and air warming in three European oak species (Quercus robur, Q. petraea and Q. pubescens). Tree Physiol 31: 287-297

Backhaus S, Wiehl D, Beierkuhnlein C, Jentsch A, Wellstein C (2014) Warming and drought do not influence the 
palatability of Quercus pubescens Willd. leaves of four European provenances. Arthropod-Plant Interact 8: 329-337

Battipaglia G, Saurer M, Cherubini P, Siegwolf RTW, Cotrufo MF (2009) Tree rings indicate different drought resistance of a native (Abies alba Mill.) and a nonnative (Picea abies (L.) Karst.) species co-occurring at a dry site in southern Italy. For Ecol Manage 257:820-828

* Beierkuhnlein C, Thiel D, Jentsch A, Willner E, Kreyling J (2011) Ecotypes of European grass species respond differently to warming and extreme drought. J Ecol 99: 703-713

Bernareggi G, Carbognani M, Petraglia A, Mondoni A (2015) Climate warming could increase seed longevity of alpine snowbed plants. Alp Bot 125:69-78

Bernareggi G, Carbognani M, Mondoni A, Petraglia A (2016) Seed dormancy and germination changes of snowbed species under climate warming: the role of preand post-dispersal temperatures. Ann Bot (Lond) 118: 529-539

Borghetti M, Cocco S, Lambardi M, Raddi S (1989) Response to water stress of Italian alder seedlings from diverse geographic origins. Can J For Res 19:1071-1076

* Borghetti M, Cinnirella S, Magnani F, Saracino A (1998) Impact of long-term drought on xylem embolism and growth in Pinus halepensis Mill. Trees (Berl) 12:187-195

* Borghetti M, Cinnirella S, Magnani F, Saracino A (2005) Effetti di carenze idriche prolungate su pinete mediterranee: insegnamenti da due esperimenti in Italia meridionale. Forest 2:31-36

Bragazza L (2008) A climatic threshold triggers the die-off of peat mosses during an extreme heat wave. Glob Change Biol 14:2688-2695

Bragazza L, Parisod J, Buttler A, Bardgett RD (2013) Biogeochemical plant-soil microbe feedback in response to climate warming in peatlands. Nat Clim Change 3:273-277

* Brancaleoni L, Gerdol R (2014) Habitat-dependent interactive effects of a heatwave and experimental fertilization on the vegetation of an alpine mire. J Veg Sci 25:427-438

Brancaleoni L, Gualmini M, Tomaselli M, Gerdol R (2007) Responses of subalpine dwarf-shrub heath to irrigation and fertilization. J Veg Sci 18:337-344

Brunetti M, Maugeri M, Nanni T, Navarra A (2002) Droughts and extreme events in regional daily Italian precipitation series. Int J Climatol 22:543-558

Brunetti M, Buffoni L, Mangianti F, Maugeri M, Nanni T (2004) Temperature, precipitation and extreme events during the last century in Italy. Global Planet Change 40: 141-149

* Bussotti F, Bettini D, Grossoni P, Mansuino S, Nibbi R, Soda C, Tani C (2002) Structural and functional traits of Quercus ilex in response to water availability. Environ Exp Bot 47:11-23

Caccianiga M, Luzzaro A, Pierce S, Ceriani RM, Cerabolini B (2006) The functional basis of a primary succession resolved by CSR classification. Oikos 112:10-20

Caloiero T, Coscarelli R, Ferrari E, Mancini M (2011) Precipitation change in Southern Italy linked to global scale oscillation indexes. Nat Hazards Earth Syst Sci 11:1683-1694

* Caloiero T, Coscarelli R, Ferrari E, Sirangelo B (2015) Analysis of dry spells in Southern Italy (Calabria). Water 7 : 3009-3023

Cannone N, Pignatti S (2014) Ecological responses of plant species and communities to climate warming: upward shift or range filling processes? Clim Change 123:201-214
Cannone N, Sgorbati S, Guglielmin M (2007) Unexpected impacts of climate change on alpine vegetation. Front Ecol Environ 5:360-364

Cannone N, Diolaiuti G, Guglielmin M, Smiraglia C (2008) Accelerating climate change impacts on alpine glacier forefield ecosystems in the European Alps. Ecol Appl 18: $637-648$

Carbognani M, Petraglia A, Tomaselli M (2012) Influence of snowmelt time on species richness, density and production in a late snowbed community. Acta Oecol 43:113-120

Carbognani M, Petraglia A, Tomaselli M (2014a) Warming effects and plant trait control on the early-decomposition in alpine snowbeds. Plant Soil 376:277-290

* Carbognani M, Tomaselli M, Petraglia A (2014b) Current vegetation changes in an alpine late snowbed community in the south-eastern Alps (Italy). Alp Bot 124:105-113

* Carbognani M, Bernareggi G, Perucco F, Tomaselli M, Petraglia A (2016) Micro-climatic controls and warming effects on flowering time in alpine snowbeds. Oecologia 182:573-585

Chapin FS (2003) Effects of plant traits on ecosystem and regional processes: a conceptual framework for predicting the consequences of global change. Ann Bot (Lond) 91:455-463

* Chelli S, Canullo R, Campetella G, Schmitt AO, Bartha S, Cervellini M, Wellstein C (2016) The response of subMediterranean grasslands to rainfall variation is influenced by early season precipitation. Appl Veg Sci 19: 611-619

* Ciccazzo S, Esposito A, Rolli E, Zerbe S, Daffonchio D, Brusetti L (2014) Different pioneer plant species select specific rhizosphere bacterial communities in a high mountain environment. SpringerPlus 3:391

Ciccazzo S, Esposito A, Borruso L, Brusetti L (2016) Microbial communities and primary succession in high altitude mountain environments. Ann Microbiol 66:43-60

Colombaroli D, Tinner W (2013) Determining the long-term changes in biodiversity and provisioning services along a transect from Central Europe to the Mediterranean. Holocene 23:1625-1634

Conti F, Abbate G, Alessandrini A, Blasi C (eds) (2005) An annotated checklist of the Italian vascular flora. Palombi Editori, Rome

Cotrufo MF, Alberti G, Inglima I, Marjanovic H and others (2011) Decreased summer drought affects plant productivity and soil carbon dynamics in a Mediterranean woodland. Biogeosciences 8:2729-2739

Cubasch U, von Storch H, Waszkewitz J, Zorita E (1996) Estimates of climate change in Southern Europe derived from dynamical climate model output. Clim Res 7: 129-149

*De Dato G, Pellizzaro G, Cesaraccio C, Sirca C and others (2006) Effects of warmer and drier climate conditions on plant composition and biomass production in a Mediterranean shrubland community. Forest 3:511-526

*De Dato G, Micali M, Abou Jaoudè R, Liberati D, De Angelis P (2013) Earlier summer drought affects leaf functioning of the Mediterranean species Cistus monspeliensis L. Environ Exp Bot 93:13-19

* Del Vecchio S, Prisco I, Acosta ATR, Stanisci A (2015) Changes in plant species composition of coastal dune habitats over a 20-year period. AoB Plants 7:plv018

* Dunne JA, Saleska SR, Fischer ML, Harte J (2004) Integrating experimental and gradient methods in ecological climate change research. Ecology 85:904-916 
Elguindi N, Rauscher SA, Giorgi F (2013) Historical and future changes in maximum and minimum temperature records over Europe. Clim Change 117:415-431

Emmett BA, Beier C, Estiarte M (2004) The response of soil processes to climate change: results from manipulation studies of shrublands across an environmental gradient. Ecosystems 7:625-637

Erschbamer B, Kiebacher T, Mallaun M, Unterluggauer P (2009) Short-term signals of climate change along an altitudinal gradient in the South Alps. Plant Ecol 202:79-89

Erschbamer B, Unterluggauer P, Winkler E, Mallaun M (2011) Changes in plant species diversity revealed by long-term monitoring on mountain summits in the Dolomites (northern Italy). Preslia 83:387-401

Evangelista A, Frate L, Carranza ML, Attorre F, Pelino G, Stanisci A (2016) Changes in composition, ecology and structure of high-mountain vegetation: a re-visitation study over 42 years. AoB Plants 8:plw004

Fady-Welterlen B (2005) Is there really more biodiversity in Mediterranean forest ecosystems? Taxon 54:905-910

Fitter AH, Fitter RSR (2002) Rapid changes in flowering time in British plants. Science 296:1689-1691

Fox LR, Ribeiro SP, Brown VK, Masters GJ, Clarke IP (1999) Direct and indirect effects of climate change on St John's wort, Hypericum perforatum L. (Hypericaceae). Oecologia 120:113-122

* Gazol A, Camarero JJ, Gutierrez E, Popa I and others (2015) Distinct effects of climate warming on populations of silver fir (Abies alba) across Europe. J Biogeogr 42: 1150-1162

Gerdol R, Petraglia A, Bragazza L, Iacumin P, Brancaleoni L (2007) Nitrogen deposition interacts with climate in affecting production and decomposition rates in Sphagnum mosses. Glob Change Biol 13:1810-1821

Gerdol R, Bragazza L, Brancaleoni L (2008a) Heatwave 2003: high summer temperature, rather than experimental fertilization, affects vegetation and $\mathrm{CO}_{2}$ exchange in an alpine bog. New Phytol 179:142-154

Gerdol R, Stanisci A, Tomaselli M (2008b) La vegetazione delle montagne italiane. Club Alpino Italiano, Milan

* Gerdol R, Siffi C, Iaucumin P, Gualmini M, Tomaselli M (2013) Advanced snowmelt affects vegetative growth and sexual reproduction of Vaccinium myrtillus in a subalpine heath. J Veg Sci 24:569-579

Giorgi F (2006) Climate change hot-spots. Geophys Res Lett 33:L08707

*Giorgi F, Lionello P (2008) Climate change projections for the Mediterranean region. Global Planet Change 63: 90-104

*Gobiet A, Kotlarski S, Beniston M, Heinrich G, Rajczak J, Stoffel M (2014) 21st century climate change in the European Alps - a review. Sci Total Environ 493:1138-1151

Gratani L, Meneghini M, Pesoli P, Crescente MF (2003) Structural and functional plasticity of Quercus ilex seedlings of different provenances in Italy. Trees (Berl) 17:515-521

Grossiord C, Gessler A, Granier A, Pollastrini M, Bussotti F, Bonal D (2014) Interspecific competition influences the response of oak transpiration to increasing drought stress in a mixed Mediterranean forest. For Ecol Manage 318:54-61

Guidotti S, Pignatti S, Testi A (2010) Microclimatic responses of plant communities to climatic changes: a study case in the Mediterranean coastal vegetation near Rome. Ann Bot (Rome) 2010:9112
Gutschick VP, BassiriRad H (2003) Extreme events as shaping physiology, ecology, and evolution of plants: toward a unified definition and evaluation of their consequences. New Phytol 160:21-42

Haeberli W, Hoelzle M, Paul F, Zemp M (2007) Integrated monitoring of mountain glaciers as key indicators of global climate change: the example of the European Alps. Ann Glaciol 46:150-160

Hsu JS, Powell J, Adler PB (2012) Sensitivity of mean annual primary production to precipitation. Glob Change Biol 18:2246-2255

* Hu B, Simon J, Kuster TM, Arend M, Siegwolf R, Rennenberg $H$ (2013) Nitrogen partitioning in oak leaves depends on species, provenance, climate conditions and soil type. Plant Biol 15:198-209

*Hughes L (2000) Biological consequences of global warming: Is the signal already apparent? Trends Ecol Evol 15: $56-61$

IPCC (2013) Climate change 2013: the physical science basis. Stocker TF, Qin D, Plattner GK, Tignor M and others (eds) Contribution of Working Group I to the Fifth Assessment Report of the Intergovernmental Panel on Climate Change. Cambridge University Press, Cambridge

ISAC-CNR (Istituto di Scienze dell'Atmosfera e del Clima. Consiglio Nazionale delle Ricerche) (2009) Clima, cambiamenti climatici globali e loro impatto sul territorio nazionale. Quaderni dell'ISAC, Vol 1. ISAC-CNR, Bologna

Jentsch A, Kreyling J, Beierkuhnlein C (2007) A new generation of climate change experiments: events, not trends. Front Ecol Environ 5:365-374

KKardol P, Campany CE, Souza L, Norby RJ, Weltzin JF, Classen AT (2010) Climate change effects on plant biomass alter dominance patterns and community evenness in an experimental old-field ecosystem. Glob Change Biol 16:2676-2687

Klein T, Di Matteo G, Rotenberg E, Cohen S, Yakir D (2013) Differential ecophysiological response of a major Mediterranean pine species across a climatic gradient. Tree Physiol 33:26-36

Kotlarski S, Bosshard T, Luthi D, Pall P, Schar T (2012) Elevation gradients of European climate change in the regional climate model COSMO-CLM. Clim Change 112:189-215

Kreyling J (2010) Winter climate change: a critical factor for temperate vegetation performance. Ecology 91:1939-1948

Kreyling J, Wiesenberg GLB, Thiel D, Wohlfart C and others (2012) Cold hardiness of Pinus nigra Arnold as influenced by geographic origin, warming and extreme summer drought. Environ Exp Bot 78:99-108

KLavorel S, Canadell J, Rambal S, Terradas J (1998) Mediterranean terrestrial ecosystem: research priorities on global change effect. Glob Ecol Biogeogr Lett 7:157-166

* Levesque M, Saurer M, Siegwolf R, Eilmann B, Brang P, Bugmann H, Rigling A (2013) Drought response of five conifer species under contrasting water availability suggests high vulnerability of Norway spruce and European larch. Glob Change Biol 19:3184-3199

* Levesque M, Siegwolf R, Saurer M, Eilmann B, Rigling A (2014) Increased water-use efficiency does not lead to enhanced tree growth under xeric and mesic conditions. New Phytol 203:94-109

* Liu ZY, Li C, Zhou P, Chen XZ (2016) A probabilistic assessment of the likelihood of vegetation drought under varying climate conditions across China. Sci Rep 6:35105 
Llorens L, Peñuelas J, Estiarte M (2003) Ecophysiological responses of two Mediterranean shrubs, Erica multiflora and Globularia alypum, to experimentally drier and warmer conditions. Physiol Plant 119:231-243

Mazza G, Manetti MC (2013) Growth rate and climate responses of Pinus pinea L. in Italian coastal sands over the last century. Clim Change 121:713-725

Medri S, Venturini S, Castellari S (2013) Overview of key climate change impacts, vulnerabilities and adaptation action in Italy. Res Pap No. 178. Centro Euro-Mediterraneo sui Cambiamenti Climatici (CMCC), Lecce

Melillo JM, McGuire AD, Kicklighter DW, Moore B, Vorosmarty CJ, Schloss AL (1993) Global climate change and terrestrial net primary production. Nature 363:234-240

Mette T, Dolos K, Meinardus C, Bräuning A and others (2013) Climatic turning point for beech and oak under climate change in Central Europe. Ecosphere 4:art145

Metz J, Tielbörger K (2016) Spatial and temporal aridity gradients provide poor proxies for plant-plant interactions under climate change: a large-scale experiment. Funct Ecol 30:20-29

* Michalet R, Schob C, Lortie CJ, Brooker RW, Callaway RM (2014) Partitioning net interactions among plants along altitudinal gradients to study community responses to climate change. Funct Ecol 28:75-86

Michelozzi M, Loreto F, Colom R, Rossi F, Calamassi R (2011) Drought responses in Aleppo pine seedlings from two wild provenances with different climatic features. Photosynthetica 49:564-572

Mondoni A, Rossi G, Orsenigo S, Probert RJ (2012) Climate warming could shift the timing of seed germination in alpine plants. Ann Bot (Lond) 110:155-164

Mondoni A, Pedrini S, Bernareggi G, Rossi G and others (2015) Climate warming could increase recruitment success in glacier foreland plants. Ann Bot (Lond) 116: 907-916

Motta R, Nola P (2001) Growth trends and dynamics in subalpine forest stands in the Varaita Valley (Piedmont, Italy) and their relationships with human activities and global change. J Veg Sci 12:219-230

Myers N, Mittermeier RA, de Fonseca GAB, Kent J (2000) Biodiversity hotspots for conservation priorities. Nature 403:853-858

Nicotra AB, Atkin OK, Bonser SP, Davidson AM and others (2010) Plant phenotypic plasticity in a changing climate. Trends Plant Sci 15:684-692

* Ogaya R, Peñuelas J (2003) Comparative field study of Quercus ilex and Phyllirea latifolia: photosynthetic response to experimental drought conditions. Environ Exp Bot 50:137-148

* Orsenigo S, Abeli T, Rossi G, Bonasoni P, Pasquaretta C, Gandini M, Mondoni A (2015) Effects of autumn and spring heat waves on seed germination of high mountain plants. PLOS ONE 10:e0133626

* Parolo G, Rossi G (2008) Upward migration of vascular plants following a climate warming trend in the Alps. Basic Appl Ecol 9:100-107

Pauli H, Gottfried M, Grabherr G (1996) Effects of climate change on mountain ecosystems - upward shifting of alpine plants. World Resour Rev 8:382-390

Pauli $\mathrm{H}$, Gottfried M, Dullinger S, Abdaladze O and others (2012) Recent plant diversity changes on Europe's mountain summits. Science 336:353-355

* Peñuelas J, Gordon C, Llorens L, Nielsen T and others (2004) Non-intrusive field experiments show different plant responses to warming and drought among sites, seasons and species in a North-South European gradient. Ecosystems 7:598-612

* Peñuelas J, Prieto P, Beier C, Cesaraccio C and others (2007) Response of plant species richness and primary productivity in shrublands along a north-south gradient in Europe to seven years of experimental warming and drought. Reductions in primary productivity in the heat and drought year of 2003. Glob Change Biol 13:2563-2581

Pereira JS, Chaves MM (1993) Plant water deficits in Mediterranean ecosystems. In: Smith JAC, Griffiths H (eds) Water deficits. Plant responses from cell to community. Bios Scientific, Oxford, p 237-251

* Peruzzi L, Conti F, Bartolucci F (2014) An inventory of vascular plants endemic to Italy. Phytotaxa 168:1-75

* Pesoli P, Gratani L, Larcher W (2003) Responses of Quercus ilex from different provenances to experimentally imposed water stress. Biol Plant 46:577-581

Petraglia A, Tomaselli M, Petit Bon M, Delnevo M, Chiari G, Carbognani M (2014) Responses of flowering phenology of snowbed plants to an experimentally imposed extreme advanced snowmelt. Plant Ecol 215:759-768

* Piccarreta M, Lazzari M, Pasini A (2015) Trends in daily temperature extremes over the Basilicata region (southern Italy) from 1951 to 2010 in a Mediterranean climatic context. Int J Climatol 35:1964-1975

* Piovesan G, Biondi F, Di Filippo A, Alessandrini A, Maugeri $M$ (2008) Drought-driven growth reduction in old beech (Fagus sylvatica L.) forests of the central Apennines, Italy. Glob Change Biol 14:1265-1281

* Reyer CPO, Leuzinger S, Rammig A, Wolf A and others (2013) A plant's perspective of extremes: terrestrial plant responses to changing climate variability. Glob Change Biol 19:75-89

* Ripullone F, Borghetti M, Raddi S, Vicinelli E and others (2009) Physiological and structural changes in response to altered precipitation regimes in a Mediterranean macchia ecosystem. Trees (Berl) 23:823-834

* Rita A, Gentilesca T, Ripullone F, Todaro L, Borghetti M (2014) Differential climate-growth relationships in Abies alba Mill. and Fagus sylvatica L. in Mediterranean mountain forests. Dendrochronologia 32:220-229

Koot TL, Price JT, Hall KR, Shneider SH, Rosenzweig C, Pounds JA (2003) Fingerprints of global warming on wild animals and plants. Nature 421:57-60

Rustad LE (2006) From transient to steady-state response of ecosystems to atmospheric $\mathrm{CO}_{2}$-enrichment and global climate change: conceptual challenges and need for an integrative approach. Plant Ecol 182:43-62

* Sala OE, Chapin FS, Armesto JJ, Berlow R and others (2000) Global biodiversity scenarios for the year 2100. Science 287:1770-1774

* Sandel B, Goldstein LJ, Kraft NJB, Okie JG and others (2010) Contrasting trait responses in plant communities to experimental and geographic variation in precipitation. New Phytol 188:565-575

Scheifinger H, Menzel A, Koch E, Peter C (2003) Trends of spring time frost events and phenological dates in central Europe. Theor Appl Climatol 74:41-51

* Senatore A, Mendicino G, Smiatek G, Kunstmann H (2011) Regional climate change projections and hydrological impact analysis for a Mediterranean basin in Southern Italy. J Hydrol (Amst) 399:70-92

* Simolo C, Brunetti M, Maugeri M, Nanni T, Speranza A (2010) Understanding climate change-induced variations 
in daily temperature distributions over Italy. J Geophys Res Atmos 115:D22110

Simolo C, Brunetti M, Maugeri M, Nanni T (2014) Increasingly warm summers in the Euro-Mediterranean zone: mean temperatures and extremes. Reg Environ Change 14:1825-1832

Stanisci A, Pelino G, Blasi C (2005) Vascular plant diversity and climate change in the alpine belt of the central Apennines (Italy). Biodivers Conserv 14:1301-1318

Stanisci A, Frate L, Morra di Cella U, Pelino G, Petey M, Siniscalco C, Carranza ML (2016) Short-term signals of climate change in Italian summit vegetation: observations at two GLORIA sites. Plant Biosyst 150:227-235

Steger C, Kotlarski S, Jonas T, Schar C (2013) Alpine snow cover in a changing climate: a regional climate model perspective. Clim Dyn 41:735-754

Suttle KB, Thomsen MA, Power MA (2007) Species interactions reverse grassland responses to changing cimate. Science 315:640-642

Tardella FM, Piermarteri K, Malatesta L, Catorci A (2016) Environmental gradients and grassland trait variation: insight into the effects of climate change. Acta Oecol 76: 47-60

Theurillat JP, Guisan A (2001) Potential impact of climate change on vegetation in the European Alps: a review. Clim Change 50:77-109

* Thiel D, Nagy L, Beierkuhnlein C, Huber G, Jenstch A, Konnert M, Kreyling J (2012) Uniform drought and warming responses in Pinus nigra provenances despite specific overall performances. For Ecol Manage 270:200-208

Thomas CD, Cameron A, Green RE, Bakkenes M and others (2004) Extinction risk from climate change. Nature 427: 145-148

Thuiller W, Lavorel S, Araùjo MB, Sykes MT, Prentice C (2005) Climate change threats to plant diversity in Europe. Proc Natl Acad Sci USA 102:8245-8250

Tognetti R, Michelozzi M, Borghetti M (1994) Response to light of shade-grown beech seedlings subjected to different watering regimes. Tree Physiol 14:751-758

Tognetti R, Johnson JD, Michelozzi M (1995) The response of European beech (Fagus sylvatica L.) seedlings from two Italian populations to drought and recovery. Trees (Berl) 9:348-354

Editorial responsibility: Tim Sparks, Cambridge, UK
Tognetti R, Michelozzi M, Giovannelli A (1997) Geographical variation in water relations, hydraulic architecture and terpene composition of Aleppo pine seedlings from Italian provenances. Tree Physiol 17:241-250

* Tomozeiu R, Pavan V, Cacciamani C, Amici M (2006) Observed temperature changes in Emilia-Romagna: mean values and extremes. Clim Res 31:217-225

Turco M, Vezzoli R, De Ronco P, Mercogliano P (2013) Variation in discharge, precipitation and temperature in Po river and tributaries basins. Res Pap No. 185. Centro Euro-Mediterraneo sui Cambiamenti Climatici (CMCC), Lecce

* Viola F, Liuzzo L, Noto LV, Lo Conti F, La Loggia G (2014) Spatial distribution of temperature trends in Sicily. Int J Climatol 34:1-17

Višnjić C, Dohrenbusch A (2004) Frostresistenz und Phänologie europäischer Buchenprovenienzen (Fagus sylvatica L.). Allg Forst Jagdztg 175:101-108

Walther GR, Post E, Convey P, Menzel A and others (2002) Ecological responses to recent climate change. Nature 416:389-395

* Wellstein C, Cianfaglione K (2014) Impact of extreme drought and warming on survival and growth characteristics of different provenances of juvenile Quercus pubescens Willd. Folia Geobot 49:31-47

*Wellstein C, Chelli S, Campetella G, Bartha S, Galiè M, Spada F, Canullo R (2013) Intraspecific phenotypic variability of plant functional traits in contrasting mountain grasslands habitats. Biodivers Conserv 22:2353-2374

* Wellstein C, Campetella G, Spada F, Chelli S, Mucina L, Canullo R, Bartha S (2014) Context-dependent assembly rules and the role of dominating grasses in semi-natural abandoned sub-Mediterranean grasslands. Agric Ecosyst Environ 182:113-122

* Xu ZZ, Jiang YL, Zhou GS (2016) Nitrogen cycles in terrestrial ecosystems: climate change impacts and mitigation. Environ Rev 24:132-143

*Yahdjian L, Sala OE (2002) A rainout shelter design for intercepting different amounts of rainfall. Oecologia 133:95-101

Zampieri M, Giorgi F, Lionello P, Nikulin G (2012) Regional climate change in the Northern Adriatic. Phys Chem Earth 40-41:32-46

Submitted: September 9, 2016; Accepted: November 11, 2016 Proofs received from author(s): February 8, 2017 